\title{
SOSIALISASI KENAKALAN REMAJA MILENIAL
}

\author{
Ibnu Supriyadi \\ Progam Studi Ilmu Administrasi Negara \\ Sekolah Tinggi Ilmu Administrasi Pembangunan Jember \\ *Email: Ibnusupriyadi@gmail.com
}

\begin{abstract}
ABSTRAK
Remaja adalah masa peralihan dari kanak-kanak ke dewasa. Seorang remaja sudah tidak lagi dapat dikatakan sebagai kanak-kanak, namun ia

masih belum cukup matang untuk dapat dikatakan dewasa. Ia sedang mencari pola hidup yang paling sesuai baginya dan inipun sering dilakukan melalui metoda coba-coba walaupun melalui banyak kesalahan. Kesalahan yang dilakukannya sering menimbulkan kekuatiran serta perasaan yang tidak menyenangkan bagi lingkungannya, orangtuanya. Kesalahan yang diperbuat para remaja hanya akan menyenangkan teman sebayanya. Hal ini

karena mereka semua memang sama-sama masih dalam masa mencari identitas. Kesalahan-kesalahan yang menimbulkan kekesalan lingkungan inilah yang sering disebut sebagai kenakalan remaja.

Remaja merupakan aset masa depan suatu bangsa. Di samping hal-hal yang menggembirakan dengan kegiatan remaja-remaja pada waktu yang akhirakhir ini dan pembinaan yang dilakukan oleh organisasi-organisasi pelajar dan mahasiswa, kita melihat pula arus kemorosotan moral yang semakin melanda di kalangan sebagian pemuda-pemuda kita, yang lebih terkenal dengan sebutan kenakalan remaja. Dalam surat kabar-surat kabar sering kali kita membaca berita tentang perkelahian pelajar, penyebaran narkotika, pemakaian obat bius, minuman keras, penjambret yang dilakukan oleh anak-anak yang berusia belasan tahun, meningkatnya kasuskasus kehamilan di kalangan remaja putri dan lain sebagainya. Hal tersebut adalah merupakan suatu masalah yang dihadapi masyarakat yang kini semakin marak, Oleh karena itu masalah kenakalan remaja seyogyanya mendapatkan perhatian yang serius dan terfokus untuk mengarahkan remaja ke arah yang lebih positif, yang titik beratnya untuk terciptanya suatu sistem dalam menanggulangi kenakalan di kalangan remaja.
\end{abstract}

Kata kunci : Kenakalan, Remaja, Masyarakat 


\section{A. Analisis Situasi}

Remaja adalah masa peralihan dari kanak-kanak menuju remaja dan ke dewasa. Seorang remaja sudah tidak lagi dapat dikatakan sebagai kanak-kanak, namun ia masih belum cukup matang untuk dapat dikatakan dewasa. Ia sedang mencari pola hidup yang paling sesuai baginya dan inipun sering dilakukan dengan cara mencoba hal-hal yang baru dikenalnya walaupun melalui banyak kesalahan. Kesalahan yang dilakukannya sering menimbulkan kekuatiran serta perasaan yang tidak menyenangkan bagi lingkungannya, orangtuanya. Kesalahan yang diperbuat para remaja hanya akan menyenangkan diri sendiri dan teman sebayanya. Hal ini karena mereka semua memang sama-sama masih dalam masa mencari identitas diri. Kesalahan-kesalahan yang menimbulkan kekesalan lingkungan inilah yang sering disebut sebagai kenakalan remaja.

Remaja merupakan aset masa depan dari suatu bangsa. Di samping hal-hal yang menggembirakan dengan kegiatan positif dan prestasi yang diraih remaja-remaja pada waktu akhir-akhir ini serta pembinaan yang dilakukan oleh organisasi-organisasi pelajar dan mahasiswa, kita juga melihat arus kemorosotan moral yang semakin melanda di kalangan sebagian pemuda-pemuda kita, yang sering terkenal dengan sebutan kenakalan remaja. Dalam pemberitaan dimedia cetak dan media ditelevisi sering kali kita menemui berita tentang perkelahian pelajar, penyebaran narkotika, minuman keras, penjambret dan pencurian lainnya yang dilakukan anak-anak berusia belasan tahun serta meningkatnya kasus-kasus kehamilan di kalangan remaja putri dan lain sebagainya.

Hal tersebut merupakan suatu masalah dari kenakalan remaja yang dihadapi oleh masyarakat yang kini semakin marak terjadi, Oleh karena itu masalah kenakalan remaja seharusnya mendapatkan perhatian yang serius dan terfokus untuk mengarahkan remaja ke arah yang lebih positif, yang tujuannya untuk terciptanya suatu sistem dalam menanggulangi kenakalan di kalangan remaja. 


\section{B. Landasan Teori}

\section{Pengertian Kenakalan Remaja}

Kenakalan remaja adalah semua perubahan sikap atau perilaku anak remaja (usia belasan tahun) yang berlawanan dengan ketertiban umum (nilai dan norma yang diakui bersama) yang ditujukan pada orang, binatang, dan barang-barang yang dapat menimbulkan bahaya atau kerugian pada pihak lain Kenakalan remaja meliputi semua perilaku yang menyimpang dari norma-norma hukum pidana yang dilakukan oleh remaja. Perilaku tersebut akan merugikan dirinya sendiri dan orangorang di sekitarnya.

Definisi kenakalan remaja menurut para ahli :

\section{Mussen}

- Perilaku yang melanggar hukum atau kejahatan yang biasanya dilakukan oleh anak remaja yang berusia 16-18 tahun, jika perbuatan ini dilakukan oleh orang dewasa maka akan mendapat sangsi hukum.

2. Santrock

Kenakalanremajamerupakankumpula ndariberbagaiperilakuremaja yang tidakdapat di terima secara social hingga terjadi tindakan kriminal.
3. Drs.B.Simanjutak,S.H.

Perbuatan-perbuatan anak remaja yang bertentangan dengan normanorma yang ada dalam masyarakat di mana ia hidup,atau suatu perbuatan anti sosial di mana di dalamnya terkandung unsure-unsur anti normatif.

\section{Kartono}

Kenakalan remaja atau dalam bahasa inggris di kenal dengan istilah juvenile delinquency merupakan gejala patologis pada remaja di sebabkan oleh satu bentuk pengabaian sosial.

\section{Paul Moedikdo}

Semua perbuatan yang dari orang dewasa merupakan suatu kejahatan bagi anak-anak merupakan kenakalan jadi semua yang dilarang oleh hukum pidana, seperti mencuri, menganiaya dan sebagainya.

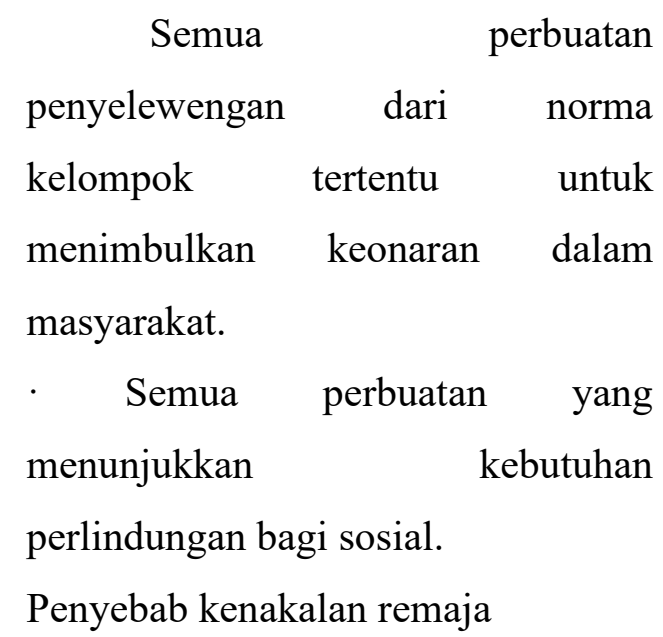


Ulah atau tindakan para remaja yang masih dalam tarap pencarian jati diri sering sekali mengusik ketenangan orang lain. Kenakalan-kenakalan ringan yang mengganggu

ketentraman

lingkungan sekitar seperti sering keluar malam dan menghabiskan waktunya hanya untuk hura-hura seperti minum-minuman keras, menggunakan obat-obatan terlarang, berkelahi, berjudi, dan lain-lainnya itu akan merugikan dirinya sendiri, keluarga, dan orang lain yang ada disekitarnya.

Cukup banyak faktor yang melatar belakangi terjadinya kenakalan remaja. Berbagai faktor yang ada tersebut dapat dikelompokkan menjadi faktor internal dan faktor eksternal.

Faktor yang menyebabkan terjadinya kenakalan remaja secara umum dapat dikelompokan ke dalam dua faktor, yaitu sebagai berikut:

1. Faktor Intern

Faktor Kepribadian

Kepribadian adalah suatu organisasi yang dinamis pada sistem psikosomatis dalam individu yang turut menentukan caranya yang unik dalam menyesuaikan dirinya dengan lingkungannya (biasanya disebut karakter psikisnya). Masa remaja dikatakan sebagai suatu masa yang berbahaya. Pada periode ini, seseorang meninggalkan masa anakanak untuk menuju masa dewasa. Masa ini di rasakan sebagai suatu Krisis identitas karena belum adanya pegangan, sementara kepribadian mental untuk menghindari timbulnya kenakalan remaja atau perilaku menyimpang.

b) Faktor Kondisi Fisik

Faktor ini dapat mencakup segi cacat atau tidaknya secara fisik dan segi jenis kelamin. Ada suatu teori yang menjelaskan adanya kaitan antara cacat tubuh dengan tindakan menyimpang (meskipun teori ini belum teruji secara baik dalam kenyataan hidup). Menurut teori ini, seseorang yang sedang mengalami cacat fisik cenderung mempunyai rasa kecewa terhadap kondisi hidupnya. Kekecewaan tersebut apabila tidak disertai dengan pemberian bimbingan akan menyebabkan si penderita cenderung berbuat melanggar tatanan hidup bersama sebagai perwujudan 
kekecewaan akan kondisi tubuhnya.

c) Faktor Status dan Peranannya di Masyarakat

Seseorang anak yang pernah berbuat menyimpang terhadap hukum yang berlaku, setelah selesai menjalankan proses sanksi hukum (keluar dari penjara), sering kali pada saat kembali ke masyarakat status atau sebutan "eks narapidana" yang diberikan oleh masyarakat sulit terhapuskan sehingga anak tersebut kembali melakukan tindakan penyimpangan hukum karena meresa tertolak dan terasingkan.

\section{Faktor Ekstern}

a. Kondisi Lingkungan Keluarga

Khususnya di kota-kota besar di Indonesia, generasi muda yang orang tuanya disibukan dengan kegiatan bisnis sering mengalami kekosongan batin karena bimbingan dan kasih sayang langsung dari orang tuanya sangat kurang. Kondisi orang tua yang lebih mementingkan karier daripada perhatian kepada anaknya akan menyebabkan munculnya perilaku menyimpang terhadap anaknya. Kasus kenakalan remaja yang muncul pada keluarga kaya bukan karena kurangnya kebutuhan materi melainkan karena kurangnya perhatian dan kasih sayang orang tua kepada anaknya.

b. Kontak Sosial dari Lembaga Masyarakat Kurang Baik atau Kurang Efektif

Apabila system pengawasan lembaga-lembaga sosial masyarakat terhadap pola perilaku anak muda sekarang kurang berjalan dengan baik, akan memunculkan tindakan penyimpangan terhadap nilai dan norma yang berlaku. Misalnya, mudah menoleransi tindakan anak muda yang menyimpang dari hukum atau norma yang berlaku, seperti mabuk-mabukan yang dianggap hal yang wajar, tindakan perkelahian antara anak muda dianggap hal yang biasa saja. Sikap kurang tegas dalam menangani tindakan penyimpangan perilaku ini akan semankin meningkatkan kuantitas dan kualitas tindak penyimpangan di kalangan anak muda.

Kondisi Geografis atau Kondisi Fisik Alam

Kondisi alam yang gersang, kering, dan tandus, dapat juga 
menyebabkan terjadinya tindakan yang menyimpang dari aturan norma yang berlaku, lebih-lebih apabila individunya bermental negative. Misalnya, melakukan tindakan pencurian dan mengganggu ketertiban umum, atau konflik yang bermotif memperebutkan kepentingan ekonomi.

Faktor Kesenjangan Ekonomi dan Disintegrasi Politik

Kesenjangan ekonomi antara orang kaya dan orang miskin akan mudah memunculkan kecemburuan sosial dan bentuk kecemburuan sosial ini bisa mewujudkan tindakan perusakan, pencurian, dan perampokan. Disintegrasi politik (antara lain terjadinya konflik antar partai politik atau terjadinya peperangan antar kelompok dan perang saudara) dapat mempengaruhi jiwa remaja yang kemudian bisa menimbulkan tindakan-tindakan menyimpang.

e. Faktor Perubahan Sosial Budaya yang Begitu Cepat

Perkembangan teknologi di berbagai bidang khususnya dalam teknologi komunikasi dan hiburan yang mempercepat arus budaya asing yang masuk akan banyak mempengaruhi pola tingkah laku anak menjadi kurang baik, lebih-lebih anak tersebut belum siap mental dan akhlaknya, atau wawasan agamanya masih rendah sehingga mudah berbuat hal-hal yang menyimpang dari tatanan nilai-nilai dan norma yang berlaku.

Gejala atau tanda-tanda seorang remaja mengalami kenakalan remaja

1. anak-anak tidak disukai oleh teman-temannya sehingga anak tersebut menyendiri.

2. Anak-anak yang sering menghindarkan diri dari tanggung jawab di rumah atau sekolah.

3. Anak-anak yang sering mengeluh dalam arti bahwa mereka mengalami masalah yang oleh dia sendiri tidak sanggup mencari permasalahannya.

4. Anak-anak yang suka berbohong.

5. Anak-anak yang tidak sanggup memusatkan perhatian.

6. Anak-anak yang mengalami phobia dan gelisah dalam melewati batas yang berbeda dengan ketakutan anak-anak normal.

7. Anak-anak yang suka menyakiti / 
mengganggu teman-temannya disekolah atau dirumah.

Perilaku-perilaku yang merupakan kenakalan remaja

$$
\text { Berdasarkan pengertian }
$$

kenakalan remaja diatas kami mengadakan pengamatan tentang beberapa perilaku remaja yang termasuk kenalan remaja di lingkungan sekitar, berikut beberapa contoh kenakalan remaja yang ada di lingkungan sekitar kami :

a) perbuatan awal pencurian meliputi perbuatan berkata bohong dan tidak jujur;

b) perkelahian antar siswa termasuk juga tawuran antar pelajar;

c) mengganggu teman baik disekolah maupun dilingkungan sekitarnya;

d) memusuhi orang tua dan saudara, meliputi perbuatan berkata kasar dan tidak hormat pada orang tua dan saudara;

e) Merokok dan pulang kerumah larut malam atau begadang;

f) menonton video atau media cetak yang tidak layak

g) Corat-coret tembok, dan fasilitas lainya yang ada di sekolah

h) Membolos dan i) Mengendarai kendaraan di bawah umur tanpa helm serta ikut balapan liar

j) Selalu melanggar tata tertib

Jadi, dapat disimpulkan tindakan kenakalan remaja sangat merugikan bagi remaja dan masyarakat itu sendiri.

\section{Identifikasi dan Perumusan} Masalah

Dari uraian tersebut di atas, maka identifikasi dan rumusan masalah adalah sebagai berikut "Bagaimanakah cara memberikan pemahaman tentang cara menangani permasalahan sosial pada kenakalan remaja"

\section{Tujuan Kegiatan Kegiatan pengabdian pada masyarakat}

Adapun tujuan progam pengabdian kepada masyarakat ini yaitu sebagai:

- Tindakan preventif, yaitu tindakan untuk mengantisipasi terjadinya kenakalan remaja

- Tindakan represif, yaitu memberikan sanksi tegas kepada pelaku kenakalan remaja

- Tindakan kuratif dan rehabilitasi, yaitu mengubah tingkah laku 
pelanggar remaja itu dengan memberikan pendidikan lagi.

\section{E. Kerangka Pemecahan Masalah}

Berdasarkan kebutuhan di lapangan diperoleh gambaran bahwa masyarakat dusun Karangkongkap adalah salah satu dusun yang berada di desa Sruni yang keadaan sosial terkait kenakalan remaja.

\section{F. Khalayak Sasaran Kegiatan}

Penyuluhan ini diikuti oleh 20 orang yang terdiri dari ibu-ibu, pemuda, dan masyarakat lainnya dari desa Sruni khususnya masyarakat dusun Darungan dan Karangkongkap Kecamatan Jenggawah Kabupaten Jember dengan harapan kelompok masyarakat tersebut dapat mengurangi kenakalan remaja.

Metode Kegiatan Kegiatan ini diawali dengan survey lapangan terlebih dahulu permohonan jin kepada penanggung jawab wilayah mengumpulkan warga setempat untuk pelaksanaan kegiatan Sosialisasi.

\section{G. Evaluasi Kegiatan}

Evaluasi kegiatan ini dilakukan dengan pemantauan setelah pelaksanaan kegiatan penyuluhan ini, yaitu semakin mengurangnya kenakalan remaja.

Masalah kenakalan remaja mulai mendapat perhatian masyarakat secara khusus sejak terbentuknya peradilan untuk anakanak nakal (juvenile court) pada 1899 di Illinois, Amerika Serikat. Kenakalan remaja meliputi semua perilaku yang menyimpang dari norma-norma hukum pidana yang dilakukan oleh remaja. Perilaku tersebut akan merugikan dirinya sendiri dan orang-orang di sekitarnya.

Faktor yang melatar belakangi terjadinya kenakalan remaja dapat dikelompokkan menjadi faktor internal dan faktor eksternal. Faktor internal berupa krisis identitas dan kontrol diri yang lemah. Sedangkan faktor eksternal berupa kurangnya perhatian dari orang tua; minimnya pemahaman tentang keagamaan; pengaruh dari lingkungan sekitar dan pengaruh budaya barat serta pergaulan dengan 
teman sebaya; dan tempat pendidikan.

Akibat-akibat yang ditimbulkan oleh kenakalan remaja akan berdampak kepada diri remaja itu sendiri, keluarga, dan lingkungan masyarakat.

Solusi dalam menanggulangi kenakalan remaja dapat dibagi ke dalam tindakan preventif, tindakan represif, dan tindakan kuratif dan rehabilitasi. Adapun solusi internal bagi seorang remaja dalam mengendalikan kenakalan remaja antara lain:

Kegagalan mencapai identitas peran dan lemahnya kontrol diri bisa dicegah atau diatasi dengan prinsip keteladanan Adanya motivasi dari keluarga, guru, teman sebaya untuk melakukan point pertama Remaja menyalurkan energinya dalam berbagai kegiatan positif

Kedua, Remaja pandai memilih teman dan lingkungan yang baik serta orangtua memberi arahan dengan siapa dan di komunitas mana remaja harus bergaul,

Ketiga, Remaja membentuk ketahanan diri agar tidak mudah terpengaruh jika ternyata teman sebaya atau komunitas yang ada tidak sesuai dengan harapan

Segala usaha pengendalian kenakalan remaja harus ditujukan ke arah tercapainya kepribadian remaja yang mantap, serasi dan dewasa. Keempat, Remaja diharapkan akan menjadi orang dewasa yang berpribadi kuat, sehat jasmani dan rohani, teguh dalam kepercayaan (iman) sebagai anggota masyarakat, bangsa dan tanah air.

\section{DAFTAR PUSTAKA}

Adilla, N. (2009). Pengaruh Kontrol Sosial terhadap Perilaku Bullying Pelajar di Sekolah Menengah Pertama. Jurnal Kriminologi Indonesia, Vol. $5: 56-66$.

Anganthi, N. R. A., Purwandari, E., \& Purwanto, Y. (2010). Pola delinquency penyalahgunaan napza di surakarta. Laporan Penelitian Fundamental Research Dikti.

Bagong, S. \& Narwoko D. (2010). Sosiologi Teks Pengantar Dan Terapan. Jakarta: Kencana. 
Basrowi, M, S. (2005). Pengantar Sosiologi. Bogor: Ghalia Indonesia.

Bruce G. Simons-Morton, A. D. (1999). Student-School Bonding and Adolescent Problem Behavior. Munchen: Health Dissestation.

Bungin, B. (2008). Analisis data penelitian kualitatif. Jakarta: PT. Raja Grafindo Persada.

Cresswell, J. W. (2012). Reseach Design Pendekatan Kualitatif, Kuantitatif, dan Mixed. Yogyakarta: Pustaka Pelajar.

Cunningham, N. J. (2007). Level of Bonding to School and Perception of to School Environment by Bullies, Victims and Bully Vivtims. Journal of Early Adolescence, 457-475.

Downing, Steven. (2010). Social Control in a Subculture of Piracy. Journal of Criminal Justice and Popular Culture, 14 (1), 77-123.
Gunarsa, S. \& J, Y. S. (2011). Psikologi Praktis: Anak, Remaja dan Keluarga. Jakarta: PT. BPK Gunung Mulia. 